MÁRIA POTOČÁROVÁ

Forum Pedagogiczne

Wydziat Filozoficzny

$9(2019) 2$, cz. 2

Katedra Pedagogiki

Wpłynęło: 15.10.2019

Uniwersytet Komeńskiego w Bratysławie

Słowacja

ORCID ID https://orcid.org/oooo-ooo2-66o8-3449

\title{
PRZYWIĄZANIE PODSTAWĄ WYCHOWANIA RODZINNEGO DO RELACJI ${ }^{1}$
}

Streszczenie: Autorka z perspektywy interdyscyplinarnej prezentuje wybrane teorie wyjaśniające fenomen przywiązania i odczytuje go w kontekście wychowania rodzinnego. Przez to eklektyczne postępowanie zmierza do wyodrębnienia wiedzy adekwatnej do potrzeb współczesnych rodziców, których kompetencje w zakresie relacji wewnątrzrodzinnych wydają się niewystarczające i wymagają podjęcia działania pedagogicznego.

Artykuł składa się z pięciu sekcji. W pierwszej przedmiotem analizy jest fenomen przywiązania w ujęciu teorii J. Bowlby'ego. W drugiej sekcji zidentyfikowano go w wychowaniu rodzinnym. Trzecia sekcja zawiera wskazania odnośnie sposobu kształtowania relacji przywiązania przez wychowanie rodzinne. W czwartej i piątej ten sam problem rozważany jest od strony rozwoju osobowości i socjalizacji rodzinnej.

Słowa kluczowe: przywiązanie; relacja; rodzice; dziecko; wychowanie.

Codzienne życie stawia rodziców przed problemami, do których rozwiązania konieczne są kompetencje interpersonalne, a w szczególności te odnoszące się do relacji z dziećmi. W tym kontekście niepokojem musi napawać fakt, że rodzicom nierzadko brakuje tak pojmowanych umiejętności dialogicznych. Ten brak świadczy moim zdaniem o pilnej potrzebie promowania „edukacji relacyjnej”. Celem tej edukacji byłoby rozwijanie wiedzy pedagogicznej na temat relacji rodzinnych i praktyczne jej zastosowanie do budowania powiązań stabilnych, obustronnych, bliskich, bezpiecznych, a przy tym stanowczych i wymagających.

1 Artykuł jest zmienioną częścią tekstu pt. Przywiązanie i wychowanie $w$ rodzinie a poczucie bezpieczeństwa u dziecka, który został przygotowany we współpracy z Elżbietą Naporą i ukazał się jako rozdział w pracy zbiorowej pt. Psychospołeczne aspekty bezpieczeństwa w wymiarze indywidualnym i społecznym (Napora, Stawiarska-Lietzau, Kornacka-Skwara 2018, s. 13-30). 
Zwłaszcza z tymi dwoma ostatnimi wyróżnikami współcześni rodzice mają szczególnie wiele problemów.

Jednym ze źródeł, z których wskazana edukacja relacyjna może czerpać swoje inspiracje, są moim zdaniem teorie przywiązania. Poniżej wyjaśnię wybrane pojęcia odnoszące się do fenomenu przywiązania i przeanalizuję wyniki badań naukowych na ten temat, które mają kluczowe znaczenie z perspektywy wychowania rodzinnego. Z rozmysłem przyjmuję perspektywę interdyscyplinarną. W różnych stanowiskach - od psychoanalitycznego, przez psychologiczno-rozwojowe aż po etologiczne i socjobiologiczne - poszukuję wskazań zarówno teoretycznych, jak i praktycznych dla zaanonsowanej edukacji relacyjnej.

Niniejszy artykuł składa się z pięciu sekcji. W pierwszej przedmiotem analizy jest fenomen przywiązania w ujęciu teorii J. Bowlby'ego. W drugiej sekcji zidentyfikowano go w wychowaniu rodzinnym. Trzecia sekcja zawiera wskazania odnośnie sposobu kształtowania relacji przywiązania przez wychowanie rodzinne. W czwartej i piątej ten sam problem rozważany jest od strony rozwoju osobowości resp. socjalizacji rodzinnej.

\section{Zarys teorii przywiązania}

Za twórcę teorii przywiązania uznaje się Johna Bowlby'ego, który wyeksplikował ją w słynnej pracy pt. Childcare and the growth of love (1980). Teoria ta umożliwiła wyjaśnienie zaburzeń emocjonalnych u małych dzieci, które zostały odseparowane od swoich matek - czy to wskutek hospitalizacji, czy umieszczenia w instytucji opiekuńczo-wychowawczej, czy śmierci rodzicielki (Marchwicki 2004). Bowlby powiązał w jedno swoje doświadczenia zdobyte jako psycholog kliniczny z badaniami przyrodników, biologów i etologów, w tym Konrada Lorenza i Nikolaasa Tinbergena (Veselovský 2008). Ci ostatni dzięki analizom sposobów zachowania zwierząt wykazują, że w ich rozwoju da się wyodrębnić przełomowe momenty. Zwierzęce niemowlę przez mechanizm zwany wdrukowywaniem (ang. imprinting) przejmuje po rodzicach fundamentalną tendencję, która warunkuje jego uczenie się przez interakcje z przedstawicielami swojego gatunku.

U człowieka funkcjonuje podobny mechanizm. Jednak w znacznie większym stopniu niż u zwierząt zapewnia on istocie ludzkiej możliwość aktywnego przetwarzania środowiska, w którym żyje, a nie tylko biernego przystosowywania się do niego. Na tej podstawie można uznać, że specyficzną cechą ludzkiej natury jest przekraczanie swojej determinacji socjobiologicznej. Z pedagogicznego punktu widzenia oznacza to, że w przypadku człowieka zawsze jest możliwa eliminacja skutków negatywnych oddziaływań środowiskowych. Tak więc prawidłowości rozwojowe i ich uwarunkowania działają u człowieka tylko w relatywnie zdeterminowany sposób, pozostawiając mu przestrzeń na wolny wybór i działanie zgodne z własną wolą. 
W kontekście teorii przywiązania za szczególnie interesujący należy uznać prenatalny okres życia człowieka. Wiedza i badania psychologii prenatalnej dostarczają naukowych uzasadnien do traktowania poczętego płodu jako istoty ludzkiej, która w pełni dysponuje wszystkimi psychicznymi i fizjologicznymi właściwościami homo sapiens sapiens. Z tego też względu płód zasługuje na uznanie i ochronę, które wynikają nie tylko ze spojrzenia na niego jako nosiciela bezcennego daru życia, lecz również odpowiedzialności za jego wychowanie i kształcenie (Kornas-Biela 2003).

Wracając do teorii Bowlby'ego, należy zauważyć, że dziecko cechuje się instynktownym poczuciem zależności od matki i na tej podstawie wchodzi z nią w relację przywiązania. Wyrazem tej relacji jest potrzeba bliskości. Dziecko sygnalizuje ją matce przez różne zachowania, takie jak: płacz, uspokojenie się w jej bliskości, uśmiech, przywieranie, ssanie itp. W ten sposób w interakcjach z matką rozwijają się „wewnętrzne modele robocze”. W swoich badaniach Ainsworth i in. (1978) wykazali, że te modele powstają tuż pod koniec pierwszego roku życia i zachowują stabilność przez wiele lat. Żeby to wyjaśnić, autorzy posługują się analogią do komputera. Ich zdaniem omawiane modele zostały zapisane w implicytnej pamięci trwałej i na tej podstawie determinują tworzenie relacji zarówno w dzieciństwie, jak i dorosłości.

Należy dopowiedzieć, że Bowlby (1980) oparł swoją teorię na podejściu psychoanalitycznym. Oprócz tego czerpał wiele z etologii, która programowo odwołuje się do biologii ewolucyjnej. Odnośnie wspomnianych powyżej wewnętrznych modeli roboczych Bowlby szukał również inspiracji w psychologii kognitywnej i rozwojowej. Ta ostatnia kładzie nacisk na jakość doświadczeń dziecka z bliską osobą (Brzezińska, 200o). Zachowania matki lub osoby pełniącej jej funkcję decydują o tym, jaki typ przywiązania rozwinie się u dziecka². Jest to zależne m.in. od tego, czy matka jest dostępna, czy jest czujna i czy reaguje natychmiast na potrzeby dziecka.

Z perspektywy czasu można stwierdzić, że teoria przywiązania wywarła znaczący wpływ na badania z zakresu psychologii, psychopatologii, psychoterapii, neonatologii, pediatrii i doradztwa psychologiczno-pedagogicznego (Przetacznikowa 1973; Langmeier, Matějček 1974; Stobiecka 2001; Czub 2003; Hašto 2005; Konrádová, Gendiarová, Rybárová 2012; Adamove 2017). Mimo że dzięki tej teorii udało się rozjaśnić wiele kwestii dotyczących specyfiki ludzkiego działania, nie można na jej podstawie udzielić odpowiedzi na pytania filozoficzno-antropologiczne, takie jak: kim jest człowiek czy dokąd zmierza jego życie, a jeszcze mniej na prześwitujący w nich problem pedagogiczny - co lub kto w decydujący sposób kształtuje człowieka i jak to kształtowanie uczynić w pełni wartościowym.

2 Ainsworth i in. (1978) wyróżnili pięć typów więzi: bezpieczna, niepewna, ambiwalentna, unikająca i zdezorganizowana. 


\section{Przywiązanie a wychowanie rodzinne}

Ludzka komunikacja i wychowanie są zakodowane w relacjach rodzinnych, które mają charakter biologiczny, psychologiczny i duchowy. Właściwie ukształtowane w dzieciństwie przywiązanie do matki umożliwia dziecku w okresie dorastania poszukiwanie i znalezienie wolności, a także podjęcie odpowiedzialności. W nawiązaniu do metafory rodziny jako gniazda można powiedzieć, że bez ciepła gniazda rodzinnego nie ma swobodnego lotu (Prekopová 1993; 2001).

Jakość wychowania rodzinnego zależy od dojrzałości osobowej rodziców i ich przygotowania do pełnienia zadań rodzicielskich. W tym kontekście za kluczowe należy uznać takie układanie więzi między osobami, żeby wytworzyła się jedność rodzinna. W świetle teorii przywiązania należy pamiętać, że zanim dziecko przyjdzie na świat, rodzice już determinują jego przyszły rozwój. Dokonuje się to przez ich nastawienie do dziecka, zarówno przez przyjęcia jego istnienia, jak i sposób traktowania go jako nowego członka rodziny.

W psychologicznym, a zwłaszcza psychoanalitycznym podejściu do wychowania, podkreśla się fakt, że we wczesnym dzieciństwie nieuświadomione lub/i podświadome motywy opiekunów dziecka, takie jak ich wyobrażenia o celach, wartościach i sensie wychowania, wyciskają niezatarte piętno na dziecku i jego rozwoju (Potočárová 2009). Psychologia głębi dopowiada, że jakość postaw rodzicielskich stanowi pochodną osobistych doświadczeń wyniesionych z domu rodzinnego (Napora 2008). Negatywne doświadczenia spowodowane przykładowo życiem w rodzinie niepełnej, rozbitej, zastępczej itp. mogą utrudniać, a niekiedy nawet uniemożliwiać bycie rodzicem. Oczywiście, przyczyn niedojrzałości i nieprzygotowania rodzica do poradzenia sobie $\mathrm{z}$ wychowaniem dziecka może być i jest z pewnością znacznie więcej.

Za podsumowanie powyższych rozważań niech posłużą słowa Zdeněka Matějčeka, który pisze: „Postawy rodzicielskie rozwijają się. Rozwój ten rozpoczyna się $\mathrm{w}$ rodzinie i w doświadczeniach dziecka $\mathrm{z}$ własnymi rodzicami lub z osobami zastępującymi rodziców. Wynika z tego jednak, że ci, którzy nie mają pozytywnych doświadczeń w tym zakresie, są w niebezpieczeństwie, że ich własne postawy rodzicielskie będą zubożałe i niedoskonałe" (1996, s. 11). Tak więc środowisko rodzinne naznacza człowieka niewymazywalnym piętnem - albo dostarcza mu silnego fundamentu pod budowę stabilnych relacji, albo podcina mu skrzydła.

\section{Sposoby kształtowania przywiązania}

Jak wspomniano powyżej, formowanie się relacji przywiązania rozpoczyna się już w okresie prenatalnym. W bardziej świadomy sposób przebiega ono po urodzeniu dziecka i obejmuje najpierw kontakt cielesny, a w szczególności pierwsze reakcje rodziców na obecność dziecka, uśmiechy, uczucia wymieniane między dzieckiem a matką lub osobą spełniającą jej funkcję. To cielesne kształtowanie przywiązania 
przebiega najintensywniej w okresie od siódmego do dwudziestego czwartego miesiąca życia (Czub 2003).

Dziecko kontynuuje uczenie się przywiązania przez tworzenie relacji z osobami z najbliższego otoczenia. W wieku przedszkolnym krąg ten zasadniczo poszerza się o dorosłych i dzieci spoza tego otoczenia. W tym kontekście jednym z zadań rozwojowych jest akceptacja własnej tożsamości według przynależności płciowej. Budowanie tej części tożsamości stanie się ponownie zadaniem rozwojowym w okresie dojrzewania. Na tej podstawie człowiek dorosły jest w stanie tworzyć relację miłości, która prowadzi do małżeństwa, a następnie w przypadku kobiety - do własnej ciąży, a w przypadku mężczyzny - ciąży współmałżonki (Matějček 1996).

Z przekonaniem użyłam powyżej terminu „małżeństwo”. Uważam bowiem połączenie dwojga osób odmiennej płci za związek pierwotny i komplementarny, który dostarcza fundamentu rodzinie jako przestrzeni służącej wychowaniu potomstwa. Istnieją naukowe dowody potwierdzające tezę, że małżeństwo heteroseksualne i klasyczna rodzina nuklearna (tzn. ojciec, matka i dzieci) są konieczne dla zdrowego rozwoju psychicznego dzieci. Jak twierdzi Jacques Derrida (1993), $\mathrm{w}$ epoce postmodernizmu rodzina oparta na małżeństwie ma $\mathrm{w}$ dalszym ciągu istotne znaczenie. Rezultaty negowania różnic międzypłciowych nie są widoczne od razu. Być może obecny wielki kryzys tożsamości człowieka w tym zakresie objawi swoje skutki dopiero za kilka dekad.

Dziecko wzrasta zdrowo i bezpiecznie, gdy akceptuje swoją determinację płciową. Jeżeli w tym procesie dochodzi do konfliktu lub gdy mentalność otoczenia zmusza je do tego, żeby nie przyjmowało jako fakt, że jest chłopcem lub dziewczynką, i zaczęło wątpić w to zróżnicowanie, staje się podatne na depresję, jest niepewne i niezdolne do przyjęcia siebie samego czy zwyczajnie do zaakceptowania realiów swojej orientacji.

Nie mam tutaj bynajmniej na myśli kwestii równouprawnienia i dyskryminacji inności na podstawie orientacji seksualnej. Uważam, że jesteśmy zróżnicowani pod względem płciowym (jako mężczyzna i kobieta), a zarazem równi co do naszych praw. Te dwie sprawy w żaden sposób nie kolidują ze sobą. Bycie mężczyzną lub kobietą dotyczy bowiem tożsamości indywidualnej, kwestia równości i równouprawnienia płci odnosi się natomiast do tożsamości społecznej. Są to dwa zasadniczo odrębne punkty widzenia. Patrząc w ten sposób, zrozumiałe staje się, że płci nie można sobie wybrać ani na nią się zdecydować. Orientacja seksualna ma swoją podstawę w biologii i popędach o określonych prawidłowościach funkcjonowania. Stąd nie może być przedmiotem wyboru osobistego ani społecznego.

Z powyższych rozważań wynika niedwuznacznie niekorzystna wizja przyszłości obecnego młodego pokolenia. Prawdopodobnie szkody psychiczne spowodowane rozwodami, których liczba współcześnie nieustannie wzrasta, będą porównywalne do tych wywołanych przez chaos w kierowanym zasadniczo dobrymi chęciami myśleniu o równości płciowej. To myślenie uwidocznia się w forsowaniu ideologii płci przez media i w działaniach oświatowych i kulturalnych. Jako pedagodzy nie 
możemy tego ignorować i nie reagować. Trzeba rozpocząć niejako od nowa, tzn. od właściwego wychowania rodzinnego.

W publikacji w języku polskim (Potočárová 2009) stwierdziłam, że już przez tworzenie właściwego nastawienia do ciąży wspiera się wychowanie psychoseksualne w rodzinie. Naturalnie ta sprawa wiąże się ściślej z wychowaniem do rodzicielstwa i planowania rodziny. W badaniach podłużnych przeprowadzonych przez wspomnianych powyżej Langmeiera i Matějčeka (1974) odnośnie deprywacji potrzeb psychicznych dzieci i konsekwencji niechcianej ciąży wykazano, że antykoncepcja nie zapobiega w wystarczającym stopniu niechcianej ciąży. Zachowanie seksualne musi być oparte na wzajemnej odpowiedzialności partnerów. Odpowiedzialność ta jest cechą zintegrowanych, dojrzałych osób, które zdolne są do relacji przywiązania, tzn. potrafią zarówno same tworzyć tę relację, jak i przyjmować i odwzajemniać, a także przekazać na drodze wychowania następnemu pokoleniu. To przekonuje, że wychowania seksualnego nie można ograniczać jedynie do wymiaru prozdrowotnego. Musi się w nim zawierać również kształtowanie przywiązania jako relacji koniecznej do budowania więzi partnerskich i rodzinnych.

\section{Kształtowanie przywiązania a rozwój osobowości}

Spośród psychologicznych teorii rozwoju osobowości na szczególną uwagę zasługuje moim zdaniem teoria Erika H. Eriksona (1963; 1997; 1999; 2002). Jak wiadomo, jest on autorem koncepcji ośmiu stadiów rozwoju psychicznego i społecznego. Poniżej ograniczę się do przeanalizowania pierwszego stadium - wczesnego dzieciństwa, które moim zdaniem odgrywa newralgiczną rolę w kształtowaniu relacji przywiązania.

W poniższej tabeli przedstawiono w skrócie charakterystykę wczesnego dzieciństwa.

Tabela 1. Cechy wczesnego dzieciństwa według E. H. Eriksona

\begin{tabular}{|c|c|c|}
\hline $\begin{array}{c}\text { Stadium } \\
\text { orientacyjny wiek }\end{array}$ & Podstawowy konflikt & Cnota \\
\hline $\begin{array}{c}\text { Niemowlęctwo } \\
(\mathrm{o}-1 \mathrm{r} . \dot{\mathrm{z}} \text {. })\end{array}$ & zaufanie $\leftrightarrow$ brak zaufania & nadzieja \\
\hline
\end{tabular}

Źródło: Opracowanie własne.

Relacja matka-dziecko może stwarzać podstawę ufności wobec innych i własnych możliwości lub powodować nieufność do siebie samego i innych. Cnota nadziei oznacza wiarę w to, że człowiek może osiągnąć swoje potrzeby i pragnienia. Jeżeli dominuje ufność, umacnia się jego nadzieja, dziecko zaś zdobywa przekonanie, że jego potrzeby zostaną zaspokojone. Na podstawie tej ufności budzi się w nim relacja przywiązania do osób, od których troskliwości jest uzależnione. Jak wspomniano 
powyżej, relacja ta może przetrwać nawet całe życie. Jeżeli jednak w dziecku będzie przeważał brak ufności, zacznie postrzegać świat jako nieprzyjazny i nieprzewidywalny. Może je opanować rozczarowanie, które w przyszłości objawi się trudnościami w tworzeniu bliższych relacji międzyludzkich lub/i zachowaniami problemowymi.

W powyższym stadium dziecko nie potrafi jeszcze odróżnić siebie od otaczającego świata i nie ma pełnej świadomości własnego „ja”. Z łatwością daje się zawładnąć spontanicznym emocjom, które są wyrazem przeżywanego zadowolenia lub niezadowolenia. Emocje przyjemności bądź ich brak mają ogólny charakter i dziecko nie jest w stanie samo określić, czego mu właściwie brakuje.

Jeżeli na tym etapie rozwoju dziecko nie wytworzy w sobie podstawowej ufności, jego całe życie jest zagrożone poważnymi dysfunkcjami. Psychologowie zgodnie uważają, że w tym okresie rolę najważniejszego czynnika odgrywa jakość kontaktu matki z dzieckiem, przy czym ze szczególnym naciskiem podkreślają jego aspekt emocjonalny. Jeżeli dziecko nie czuje, że jest kochane, jeżeli nie jest mu dobrze, nie jest akceptowane, jego dalsze przystosowanie będzie trudne, frustrujące, osłabiające ufność do siebie i innych. Jeżeli rodzicom nie uda się w tym okresie zadośćuczynić potrzebie podstawowej ufności, jej miejsce zajmie poczucie tzw. podstawowej niepewności i niepokoju. Jeżeli dziecko nie ma zagwarantowanych swoich potrzeb we własnej rodzinie i nie może tego osiągnąć w żaden inny sposób, zacznie postrzegać swoje otoczenie jako zagrożenie i źródło niebezpieczeństwa. Wskutek tego w późniejszym czasie może mieć problemy przy nawiązywaniu nowych znajomości, ponieważ za każdym razem musi przezwyciężać wewnętrzny niepokój, niepewność i strach, co często kompensuje całym szeregiem mechanizmów obronnych i unikowych. Wskutek tego dziecko przeżywa podstawową niepewność jako poczucie opuszczenia i samotności w nieprzyjaznym świecie.

Do najważniejszych przyczyn powstawania niepewności i niepokoju można zaliczyć:

1. brak regularności i konsekwencji w sposobie nagradzania i karania, co sprawia, że dziecko nie rozumie, co będzie następować po czym;

2. zachowanie otoczenia - niezaangażowane pod względem emocjonalnym, co powoduje, że dziecko ma poczucie, że nikt go nie kocha;

3. wciągnięcie w konflikt między rodzicami lub innymi osobami z najbliższego otoczenia, które dziecko kocha tak samo. Jest to stan, w którym dziecko musi opowiedzieć się za jedną lub drugą stroną konfliktu, mimo że nie może, nie chce i nie potrafi tego zrobić. W skrajnym przypadku dochodzi wówczas do tzw. deprywacji psychicznej;

4. wymaganie nadmiernej odpowiedzialności, która przekracza siły i możliwości dziecka lub pozbawianie je jakiejkolwiek odpowiedzialności. Obydwa podejścia mogą prowadzić do powstania u dziecka stanów neurotycznych.

Oczywiście, wskazane powyżej przyczyny niepewności i niepokoju nie są charakterystyczne wyłącznie dla pierwszego stadium rozwojowego. Mogą pojawić się 
także w kolejnych latach życia. Chciałam jednak zwrócić uwagę na nie dlatego, że nie docenia się ich potencjalnego negatywnego wpływu już w wieku niemowlęcym. Jeżeli we wczesnym dzieciństwie nie wytworzy się podstawowa ufność, rozwój dziecka w kolejnych stadiach życia może być poważnie zagrożony. Nie zawsze uda się zrekompensować powstałe wówczas szkody i zniszczenia (Matula 2013).

\section{Kształtowanie przywiązania a socjalizacja rodzinna}

Rodzina i środowisko rodzinne stanowią dla dziecka wartości, których nie da się niczym zastąpić. Po urodzeniu dziecko potrzebuje opieki i troski rodziców, zaspokojenia potrzeb - od tych fizjologicznych aż po duchowe. W miarę wzrastania uświadamia sobie swoją (1) tożsamość jako odpowiedź na pytanie, kim jest, (2) przynależność, (3) indywidualność, czyli prawo do upodobniania się i równocześnie odróżniania się od innych, i (4) samodzielność, której wyrazem jest stopniowe przejmowanie kontroli nad swoim życiem.

Wymienione powyżej atrybuty tworzą podstawę do budowania przez dziecko szacunku do samego siebie. Mimo najlepszych chęci nie da się przekazać tych wartości w rodzinach zastępczych ani w domach dziecka. Znajdując tam konieczną opiekę i wsparcie, dziecko w zasadzie nie wie, kim jest, do kogo jest podobne, jacy są jego krewni, do kogo właściwie przynależy. Możliwości podejmowania przezeń decyzji w zakresie codziennych, drobnych spraw są mocno ograniczone. Pełny rozwój szacunku do samego siebie i poczucia własnej wartości u dziecka jest możliwy tylko w intymnym środowisku rodziny.

W tym kontekście chciałabym odwołać się do wyrażenia „bliskość rodzicielska”. Jest to tłumaczenie angielskiego zwrotu attachment parenting, którego używa się do określenia nowego kierunku w ramach doradztwa psychopedagogicznego i psychoterapii. Wydaje mi się, że z większą uwagą podchodzi się w nich do rozwijania relacji przywiązania między rodzicami a dziećmi jako podstawowego warunku zaspokojenia potrzeb biologicznych, psychologicznych i społecznych dziecka. Założeniem zdrowego rozwoju jest stabilna więź z osobą, która będzie najważniejszym punktem oparcia w jego dalszym życiu. Dziecko w pierwszych trzech latach życia potrzebuje bezpiecznego związania się (zazwyczaj) z matką, która oznacza dla niego cały świat: pokarm, miłość, bezpieczeństwo, spokój i wszystko, czego potrzebuje. Ważne są także reakcje matki na wymagania dziecka. Dobrze, gdy jest ona emocjonalnie zrównoważona, a zarazem postrzega dziecko jako odrębną indywidualność, którą szanuje i wspiera, nie zniewalając.

Wychowanie oparte na przywiązaniu pozwala odzyskać życiu rodzinnemu naturalność, w szczególności dzieciom miłość macierzyńską i „silne objęcia”3.

3 Wyrażenie „silne objęcia” nawiązuje do „terapii przez silne objęcie”, autorstwa Prekopovej (1993), która w wielu aspektach odwołuje się do teorii przywiązania. 
Choć może to zabrzmieć współcześnie dwuznacznie, ale dzięki nim dzieci mogą wrócić na ręce i do łóżek swoich rodziców.

Warto dopowiedzieć, że pionierami i propagatorami wychowania w bliskości jest małżeństwo William i Martha Searsowie (2012). Model tego wychowania przedstawili w formie sześciu filarów, inaczej narzędzi wychowawczych. Otóż, pierwszym filarem jest stworzenie tuż po porodzie początkowej więzi między matką a dzieckiem. W okresie prenatalnym matka i dziecko wspólistnieli jako jeden organizm. Byli nierozłączną parą. Teraz nie tylko dziecko, lecz także matka muszą nauczyć się żyć samodzielnie. Dla powstania nowej więzi między nimi najważniejszych jest pierwszych sześć tygodni. W tym okresie matka próbuje wsłuchiwać się w swoje dziecko i zaspokajać jego biologiczne potrzeby. Dla matki jest to czas dużych zmian emocjonalnych.

Karmienie na żądanie dziecka wyrażone płaczem jest narzędziem jego poznawania. Matka uczy się rozpoznawać, co oznacza dany rodzaj płaczu. Aby okres karmienia piersią był owocnym czasem, matka musi nauczyć się jak najdokładniej i najszybciej reagować na sygnały dawane przez dziecko. Od tego będzie zależało budowanie relacji pełnej ufności.

Noszenie dziecka na ręku jest przez współczesnych rodziców niedocenianym i często zaniedbywanym sposobem wychowania. Prawdą jest jednak, że dzieci, których rodzice nie zrezygnowali z noszenia ich na ręku, są mniej nerwowe, bardziej spostrzegawcze, a w stanie spokojnego czuwania szybciej i łatwiej się uczą. Matki noszące dzieci lepiej rozpoznają życzenia i nastroje swojego dziecka, dzięki czemu mogą adekwatnie na nie reagować. Dzieci noszone czy to na ręku, czy w nosidełku czują się bezpieczne i blisko swojej matki. Tym samym między matką a dzieckiem tworzy się relacja oparta na zaufaniu.

Spanie dziecka w pobliżu rodziców, zwłaszcza matki, jest zazwyczaj związane $z$ karmieniem na żądanie. Sen powinien być dla dziecka czasem odpoczynku, a nie strachu przed ciemnością i rozłąką. Matki powinny reagować na potrzeby swojego dziecka tak samo za dnia, jak i w nocy. Częste karmienie w nocy niemalże wymaga wspólnego spania. Jest to łatwiejsze i bardziej praktyczne zarówno dla dziecka, jak i dla matki. Matka i dziecko są jakby zestrojeni ze sobą, tzn. mają taką samą częstotliwość snu i czuwania, i często budzą się równocześnie.

Współcześnie neguje się dość banalną prawdę, że dziecko zawsze ma powód do płaczu. Wynika to stąd, że płacz jest mową dziecka. Płacze ono, gdy jest mu smutno, gdy coś je boli, gdy jest głodne lub gdy ma mokro. Zawsze płacze z jakiegoś powodu. Uważna matka uczy się rozpoznawać rodzaje płaczu swojego dziecka i im szybciej zareaguje na dany rodzaj płaczu, tym dziecko przeżywa mniejszy niepokój. Płacz jest cennym sygnałem, a dziecko nie płacze po to, aby nami manipulować, lecz aby się z nami komunikować.

Ostatnim, co nie znaczy, że najmniej ważnym filarem wychowania w bliskości, jest równowaga. Żeby być w stanie dać swojemu dziecku jak najwięcej, rodzice muszą umieć reagować także na własne potrzeby. Nie wolno dopuścić do tego, 
aby matka, poświęcając się dziecku całkowicie, zaniedbywała samą siebie, swoje potrzeby i relacje, w tym również małżeńskie.

\section{Podsumowanie}

W niniejszym artykule zaprezentowano wybrane ujęcia teoretyczne dotyczące fenomenu przywiązania, które - zdaniem autorki - da się wykorzystać w edukacji relacyjnej. Pod pojęciem tej ostatniej należy rozumieć wiedzę pedagogiczną i praktyczne sposoby działania, które są przydatne do nabywania przez rodziców kompetencji dialogicznych, w szczególności chodzi o umiejętności kultywowania relacji przywiązania $\mathrm{w}$ wychowaniu rodzinnym. U współczesnych rodziców zauważa się bowiem spore deficyty w tym zakresie i pilną potrzebę podjęcia kroków zmierzających do zaradzenia wspomnianym brakom.

Do określeniu istoty przywiązania punktem wyjścia były analizy etologów, którzy zajmując się zachowaniem zwierząt, opracowali mechanizm wdrukowywania. W celu rekonstrukcji fenomenu przywiązania autorka uwzględniła również stanowiska psychoanalizy i psychologii rozwojowej. Na tej podstawie rozpatrzyła pedagogiczne znaczenie przywiązania w odniesieniu do wychowania rodzinnego. Swoją uwagę skoncentrowała na obecności przywiązania i możliwościach celowego kształtowania tej relacji, a także na jej powiązaniu z rozwojem osobowości i socjalizacją rodzinną.

Głównym powodem powstania tego artykułu jest zauważalny deficyt w zakresie przygotowania rodziców do budowania stabilnych relacji ze swoimi dziećmi. Wydaje się, że zadaniem pedagogiki rodziny, a w szczególności zaproponowanej w niniejszym tekście edukacji relacyjnej, powinno być dostarczenie teoretycznych uzasadnień dla pilnej potrzeby wychowania do relacji i budowy pedagogicznej koncepcji takiego wychowania. Z pewnością przedstawiony problem nie został w pełni omówiony i wymaga prowadzenia dalszych badań pedagogicznych.

\section{Bibliografia}

Adamove J. (2017). Vztahová väzba v detstve a dospelosti. Bratislava: Vydavatel'stvo F, Pro mente sana.

Ainsworth M., Blehar M., Waters E., Wall S. (1978). Patterns of attachment: A psychological study of the strange situation. Hilsdale: Lawrence Erlbaum.

Bowlby J. (1980). Childcare and the growth of love. Middlesex: Penguin Books.

Brzezińska A. (200o). Społeczna psychologia rozwoju. Warszawa: Wydawnictwo Naukowe Scholar.

Czub M. (2003). Znaczenie wczesnych więzi społecznych dla rozwoju emocjonalnego dziecka. „Forum Oświatowe”, 2 (9), s. 31-49.

Derrida J. (1993). Texty k deštrukcii. Bratislava: Archa.

Erikson E. H. (2002). Dětství a společnost. Praha: Argo. 
Erikson E. H. (1963). Childhood and Society. New York: W. W. Norton.

Erikson E. H. (1997). Životní cyklus rozšírený a dokončený. Praha: Lidové noviny.

Erikson E. H. (1999). Životní cyklus rozšířený a dokončený. Praha: Nakladatelství Lidové Noviny.

Hašto J. (2005). Vztahová väzba. Trenčín: Vydavatel'stvo F, Pro mente sana.

Konrádová L., Gendiarová M., Rybárová K. (2012). Kvalita vztahovej väzby adolescentov. W: Sociálne procesy a osobnost'. Zborník príspevkov z 15. ročníka medzinárodnej konferencie. Bratislava: Ústav experimentálnej psychológie, s. 331-337.

Kornas-Biela D. (2003). Psychodynamiczny nurt w psychologii prenatalnej: wybrane problemy z obszaru prokreacji. „Przegląd Psychologiczny”, 2 (46), s. 179-196.

Langmeier J., Matějček Z. (1974). Psychická deprivace v dětství. Praha: Avicenum. Marchwicki P. (2004). Psychospołeczne uwarunkowania stylów przywiązania. „Studia Psychologica”, 5, s. 35-56.

Matějček Z. (1996). Co, kdy a jak ve výchově dětí. Praha: Portál.

Matula Š. (2013). Konflikty a ich riešenie v životných štádiách. W: Slovo medzi nami, príloha, Bratislava: Lúč.

Napora E. (2008). Obraz rodziców a cechy osobowosci pożąane w wychowaniu dziecka. Częstochowa: Wydawnictwo Akademii im. Jana Długosza.

Napora E., Potočárová M. (2018), Przywiązanie i wychowanie w rodzinie a poczucie bezpieczeństwa u dziecka, W: Napora E., Stawiarska-Lietzau M., Kornacka-Skwara E. (red.). (2018). Psychospołeczne aspekty bezpieczeństwa w wymiarze indywidualnym i społecznym. Częstochowa: Wydawnictwo UH-P im. J. Długosza, s. $13-30$.

Napora E., Stawiarska-Lietzau M., Kornacka-Skwara E. (red.). (2018). Psychospołeczne aspekty bezpieczeństwa w wymiarze indywidualnym i społecznym. Częstochowa: Wydawnictwo UH-P im. J. Długosza.

Potočárová M. (2009). Wybrane aspekty wychowania rodzinnego. Kraków: Wydawnictwo UKIP.

Prekopová J. (1993). Malý tyran. Praha: Portál.

Prekopová J. (2001). Jak být dobrým rodičem. Praha: Grada.

Przetacznikowa M. (1973). Podstawy rozwoju psychicznego dzieci i młodzieży. Warszawa: PZWS.

Sears W., Searsová M. (2012). Vztahová výchova. Praktická príručka o citlivom a prirodzenom prístupe $k$ dietatu. Zlaté Moravce: ChristBook.

Stobiecka, M. (2001). Teoria więzi w wyjaśnianiu autodestruktywności. „Forum Oświatowe", 2 (25), s. 93-109.

Veselovský Z. (2008). Etologie. Biologie chování zvírat. Praha: Academia. 


\title{
BONDING AS THE BASIS FOR FAMILY EDUCATION TO RELATIONSHIPS
}

\begin{abstract}
The author presents selected theories explaining the phenomenon of bonding by taking interdisciplinary perspective and understands it in the context of family education. Due to this eclectic approach, she aims to extract knowledge adequate to the needs of modern parents, whose competences in the field of intra-family relations seem insufficient and require pedagogical interventions.

The article consists of five sections. Section 1 analyzes the phenomenon of bonding based on J. Bowlby's theory. In the second section bonding was identified in family education. The third section provides guidance on how to shape bonding relationships through family education. In the fourth and fifth section the same problem is considered in terms of personality development and family socialization respectively.
\end{abstract}

Słowa kluczowe: bonding; relationship; parents; child; education.

Mária Potočárová - profesor, doktor habilitowana, zatrudniona w Katedrze Pedagogiki Wydziału Filozoficznego Uniwersytetu Komeńskiego w Bratysławie (Słowacja). Jej zainteresowania naukowe: pedagogika rodziny, wychowanie moralne, dydaktyka akademicka. Publikacje (monografie): Rodina, mládež a jej postoje k sociálnym limitom (2003); Pedagogika rodiny - teoretické východiská rodinnej výchovy (2008); Wybrane aspekty wychowania rodzinnego (2009); Pedagogický výskum v Oceánii (2012); Etika v rodinných vztahoch (2018). Adres korespondencyjny: Pečnianska 21, 851-01 Bratislava. Adres e-mailowy: maria.potocarova@uniba.sk. 